\title{
Suitability evaluation of underground space development in Dalian
}

\author{
Gao Mengmeng ${ }^{1}$, Yang Nan $^{1 *}$, Wang Yi $^{1}$, Li Xiaolei ${ }^{1}$, Liu Qiong ${ }^{1}$, Wu Jinhui ${ }^{1}$, Zhao Zixin ${ }^{1}$ \\ ${ }^{1}$ China Institute of Geo-Environmental Monitoring, Beijing, China
}

\begin{abstract}
Rational development and utilization of urban underground space has become an important measure to alleviate the contradiction between supply and demand of land resources, improve urban capacity and optimize urban layout. Underground space is an important part of the geological environment because of its natural resources. Unreasonable development will lead to geological environment problems. In this paper, combined with the actual situation of Dalian City, on the basis of comprehensive analysis of geological environment conditions, eight indicators are selected from the aspects of topography, engineering geological conditions, hydrogeological conditions, geological hazards, ecological factors and human activities to construct the hierarchy model of suitability evaluation for underground space development in Dalian City. The analytic hierarchy process and comprehensive index method are applied to the evaluation. The results show that: the suitable area, secondary suitable area, less suitable area and unsuitable area are $3812.58 \mathrm{~km}^{2}$, $5430.91 \mathrm{~km}^{2}, 2711.38 \mathrm{~km}^{2}$ and $1659.06 \mathrm{~km}^{2}$, accounting for $28.00 \%, 39.89 \%, 19.92 \%$ and $12.19 \%$ respectively. The evaluation results can provide the basis for the future development and utilization planning of underground space in Dalian city.
\end{abstract}

\section{Introduction}

With the rapid economic development and accelerating process of urbanization in China, and the problems of population saturation, traffic congestion and land resource shortage are becoming more and more prominent, which has become the main problems restricting the development of urbanization ${ }^{[1-3]}$. Therefore, the rational development and utilization of urban underground space has become an important measure to alleviate the contradiction between supply and demand of land resources, improve urban capacity and optimize urban pattern ${ }^{[4]}$.

Underground space has the attribute of natural resources and is an important part of geological environment. Unreasonable development will lead to geological environment problems. Therefore, it is necessary to carry out the evaluation of the suitability of the geological environment of underground space. Based on the research and analysis of the basic conditions of the geological environment of the underground space, the difficulty and suitability of regional underground space development should be evaluated, which can provide scientific basis for underground space utilization planning and optimization of urban pattern.

According to the suitability evaluation of underground space, many scholars have done a lot of research. By studying the geological environment of Sao Paulo City, Sterling ${ }^{[5]}$ comprehensively analyzed the geotechnical conditions, hydrogeological conditions, topography and other engineering geological conditions, and evaluated the suitability of underground space development and utilization through comprehensive superposition evaluation factors. De Rienzo $\mathrm{F}^{[6]}$ investigated the geological environment and the development status of underground space in Turin, Italy, and established a threedimensional model of underground space, showing the three-dimensional structure of the city's underground space. Hao A.B. ${ }^{[7]}$ proposed an integrated evaluation method for surface-underground space engineering construction suitability and and applied it to Xiongan New Area. Zhang M.S. ${ }^{[8]}$ proposed a method for evaluating underground space resources based on a negative list of adverse factors including limiting factors,constraining factors and influencing factors which affects underground space development. Peng J. ${ }^{[9]}$ established a set of evaluation model for suitability of underground space development and utilization by using analytic hierarchy process (AHP) and expert questionnaire survey and selecting the mathematical model of multi-objective linear weighting function method. He J. ${ }^{[10]}$ established an evaluation index system based on the combination of basic conditions and constraint conditions, and comprehensively evaluated the geological suitability of the development and utilization of underground space resources in Beijing plain area through fuzzy mathematics and analytic hierarchy process.

In recent years, great progress has been made in the evaluation of urban underground space development, but there is no recognized underground space development evaluation index system. In this paper, combined with the actual situation of Dalian City, on the basis of

* Corresponding author: yangn@mail.cigem.cn 
comprehensive analysis of geological environment conditions, eight indicators are selected from the aspects of topography, engineering geological conditions, hydrogeological conditions, geological hazards, ecological factors and human activities to construct the hierarchy model of suitability evaluation for underground space development in Dalian and the analytic hierarchy process and comprehensive index method are applied to the evaluation. It provides the basis for the future underground space development and utilization planning of Dalian.

\section{The overview of the study area}

Dalian is located at the southern end of Liaodong Peninsula, on the coast of the Yellow Sea and Bohai Sea, with its back to the hinterland of Northeast China and across the sea from Shandong Peninsula. It is located between $38^{\circ} 43^{\prime} \sim 40^{\circ} 12^{\prime} \mathrm{N}$ and $120^{\circ} 58^{\prime} \sim 123^{\circ}$ $31^{\prime} \mathrm{E}$, with a total land area of $13613.94 \mathrm{~km}^{2}$. The basic landform of Dalian city is high in the middle, and gradually decreases to the east and west sides until the seashore, forming the landform of mountainous and hilly peninsula. Land resources are obviously restricted by topography, the utilization efficiency of existing land resources is low, and the reserve land resources are lack, especially in the central city.

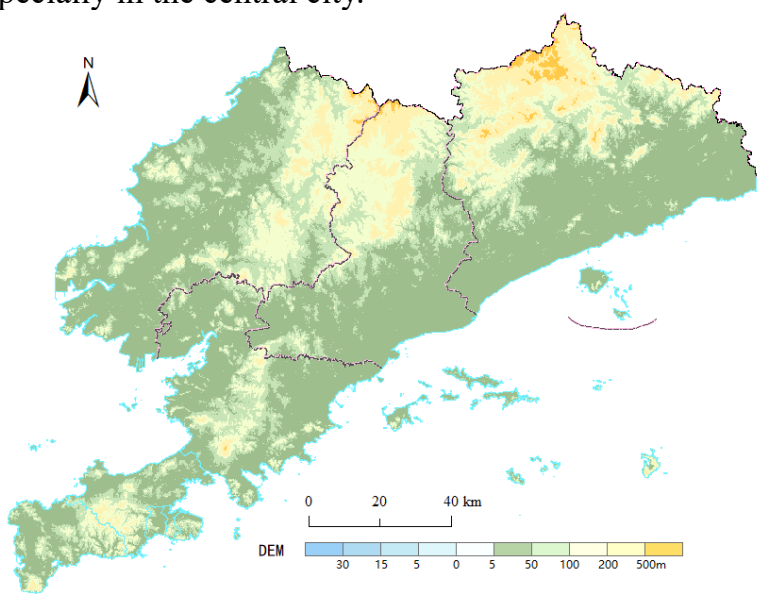

Fig .1. Topographic map of Dalian City.

\section{Evaluation method}

In this paper, the suitability of geological environment for underground space development in Dalian city is evaluated by using AHP to determine the weight of each index and comprehensive index method.

(1) Analytic hierarchy process (AHP) is a combination of qualitative and quantitative method proposed by American operational research scientist and Professor T.L.Saaty of University of Pittsburgh in the 1970s. It is widely used to solve multi-objective environmental problems. The method mainly includes the establishment of hierarchy, determination of judgment matrix, consistency test of judgment matrix, determination of weight value and other steps.

On the basis of establishing the hierarchical structure, the judgment matrix is determined first, and the evaluation is carried out according to the steps of expert scoring.

Table 1. Identification and meaning of judging matrix in the expert analytic hierarchy weighting process.

\begin{tabular}{|c|l|}
\hline Number & \multicolumn{1}{c|}{ Meaning } \\
\hline 1 & One is as important as the other \\
\hline 3 & One is slightly more important than the other \\
\hline 5 & One is more important than the other \\
\hline 7 & One is much more important than the other \\
\hline 9 & One is extremly more important than the other \\
\hline 2468 & $\begin{array}{l}\text { The median value of the above two adjacent judgments } \\
\text { indicates the transition between importance judgments }\end{array}$ \\
reciprocal & $\begin{array}{l}b_{i j} \text { is obtained by comparing i with } \mathrm{j}, b_{j i} \text { is obtained by } \\
\text { comparing } \mathrm{j} \text { with i. } b_{j i}=1 / b_{i j}\end{array}$ \\
\hline
\end{tabular}

The maximum eigenvalue and eigenvector of judgment matrix are obtained by eigenvalue method, and the corresponding weight of each index can be obtained by normalizing the eigenvector. In order to test whether the weight of the matrix is reasonable, it is necessary to test the consistency of the judgment matrix. The test formula is as follows:

$$
\begin{aligned}
C I & =\frac{\lambda \max -n}{n-1} \\
C R & =\frac{C I}{R I}
\end{aligned}
$$

$C I$ is the consistency index; $\lambda_{\max }$ is the maximum eigenvalue; $\mathrm{n}$ is the order of the matrix; $R I$ is the average random consistency index, and the values are shown in Table 2. $C R$ is the random consistency ratio. The judgment matrix is considered to be satisfactory in consistency and reasonable when $C R<0.10$.

(2) The comprehensive index method is to get the comprehensive evaluation index by weighting the index value of each evaluation factor according to the weight. In this paper, the comprehensive index of underground space development suitability is constructed, and the calculation formula is as follows:

$$
\mathrm{F}=\sum_{i=1}^{\mathrm{n}} A(i) \cdot Q(i)
$$

$\mathrm{F}$ is the suitability evaluation index; $\mathrm{n}$ is the number of evaluation factors; $A(i)$ is the weight of the ith evaluation factor; $\mathrm{Q}(i)$ is the score of the ith evaluation factor.

Table 2. Average stochastic consistency index in the analytic hierarchy process.

\begin{tabular}{|c|c|c|c|c|c|}
\hline $\mathrm{n}$ & 1 & 2 & 3 & 4 & 5 \\
\hline $\mathrm{RI}$ & 0 & 0 & 0.52 & 0.89 & 1.11 \\
\hline $\mathrm{n}$ & 6 & 7 & 8 & 9 & \\
\hline $\mathrm{RI}$ & 1.25 & 1.35 & 1.4 & 1.45 & \\
\hline
\end{tabular}

\section{Evaluation system}

\subsection{Construct hierarchical structure model}

First of all, it is necessary to determine the evaluation 
index, and the selection of evaluation index follows the principle of scientific, easy to obtain and quantifiable. Based on the comprehensive analysis of the geological environment conditions in the study area, and fully considering the influence of human activities, this paper selects the topography, engineering geological conditions, hydrogeological conditions, geological hazard, ecological factors and human activities as the criteria layer and 8 indicators are selected as the index layer. On this base, the hierarchy model of suitability evaluation in Dalian city is constructed.

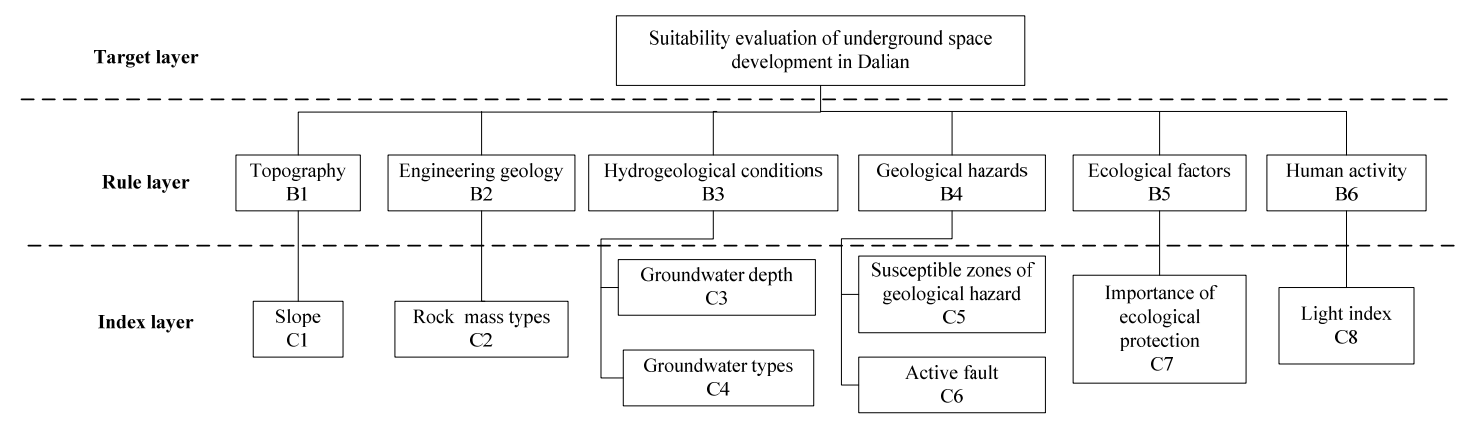

Fig.2. Hierarchical structure model

\subsection{Construct judgment matrix}

The judgment matrix is constructed for the criterion layer and the index layer respectively, and the consistency test is carried out to obtain the weight value of each factor (table 3-5). According to each judgment matrix, the weight of each criterion layer and index layer can be calculated, as shown in Table 6 ..

Table 3. Primary partition factors discriminant matrix A-B.

\begin{tabular}{|c|c|c|c|c|c|c|c|}
\hline & $\mathrm{B} 1$ & $\mathrm{~B} 2$ & $\mathrm{~B} 3$ & $\mathrm{~B} 4$ & $\mathrm{~B} 5$ & $\mathrm{~B} 6$ & weight \\
\hline $\mathrm{B} 1$ & 1 & $1 / 3$ & 1 & 1 & 7 & 1 & 0.1614 \\
\hline $\mathrm{B} 2$ & 3 & 1 & 1 & 3 & 7 & 1 & 0.2796 \\
\hline $\mathrm{B} 3$ & $1 / 1$ & $1 / 1$ & 1 & 1 & 5 & 1 & 0.1833 \\
\hline $\mathrm{B} 4$ & $1 / 1$ & $1 / 3$ & $1 / 1$ & 1 & 7 & 1 & 0.1614 \\
\hline $\mathrm{B} 5$ & $1 / 7$ & $1 / 7$ & $1 / 5$ & $1 / 7$ & 1 & $1 / 5$ & 0.0310 \\
\hline $\mathrm{B} 6$ & $1 / 1$ & $1 / 1$ & $1 / 1$ & $1 / 1$ & 5 & 1 & 0.1833 \\
\hline
\end{tabular}

Table 4. Partition factors discriminant matrix B3-C.

\begin{tabular}{|c|c|c|c|}
\hline & $\mathrm{C} 3$ & $\mathrm{C} 4$ & weight \\
\hline $\mathrm{C} 3$ & 1 & 1 & 0.5 \\
\hline $\mathrm{C} 4$ & $1 / 1$ & 1 & 0.5 \\
\hline$\lambda \max =2, \quad C R=0$ & $\mathrm{CI}=0$, meeting the consistency test standard \\
\hline
\end{tabular}

Table 5. Partition factors discriminant matrix $\mathrm{B}_{4}-\mathrm{C}$.

\begin{tabular}{|c|c|c|c|}
\hline & C5 & C6 & weight \\
\hline $\mathrm{C} 5$ & 1 & 7 & 0.875 \\
\hline $\mathrm{C} 6$ & $1 / 7$ & 1 & 0.125 \\
\hline$\lambda \max =2, \quad C R=0$ & $\mathrm{CI}=0, \quad$ meeting the consistency test standard \\
\hline
\end{tabular}

Table 6. Weight of criteria layer and index lay.

\begin{tabular}{|c|c|c|c|}
\hline Rule layer & Weight & Index layer & Weight \\
\hline Topography & 0.1614 & Slope & 0.1614 \\
\hline $\begin{array}{c}\text { Engineering } \\
\text { geology }\end{array}$ & 0.2796 & Rock mass types & 0.2796 \\
\hline $\begin{array}{c}\text { Hydrogeological } \\
\text { conditions }\end{array}$ & 0.1833 & Groundwater depth & 0.0916 \\
\cline { 3 - 4 } & Groundwater types & 0.0916 \\
\hline $\begin{array}{c}\text { Geological } \\
\text { hazards }\end{array}$ & 0.1614 & $\begin{array}{c}\text { Susceptible zones of } \\
\text { geological hazard }\end{array}$ & 0.1412 \\
\cline { 3 - 4 } & Active fault & 0.0202 \\
\hline
\end{tabular}

\begin{tabular}{|c|c|c|c|}
\hline $\begin{array}{c}\text { Ecological } \\
\text { factors }\end{array}$ & 0.031 & $\begin{array}{c}\text { Importance of } \\
\text { ecological } \\
\text { protection }\end{array}$ & 0.0310 \\
\hline $\begin{array}{c}\text { Human } \\
\text { activity }\end{array}$ & 0.1833 & Light index & 0.1833 \\
\hline
\end{tabular}

\subsection{Index classification and quantification}

In this paper, referring to the standards and specifications of ground construction, spatial planning and other relevant policy documents and standards, combined with the geological conditions of Dalian City, the grading and quantitative standards of each evaluation index are formulated. Each single index is divided into four levels, which are suitable, Secondary suitable, less suitable and unsuitable. The corresponding index quantitative scores are 10 points, 6 points, 3 points and 1 point respectively. The larger the score, the more suitable for underground engineering construction.

(1) Topography

Topography affects the development of underground space. The larger the slope, the higher the construction cost, which restricts the development of underground space. The terrain slope is divided into four grades. The smaller the slope is, the higher the suitability of underground space development is.

(2) Engineering geology

The geological bearing capacity of different rock mass types is different, and the rock mass types control the difficulty of underground space development and engineering safety. The rock types are divided into magmatic rock formation, metamorphic rock formation, clastic rock formation and carbonate formation. The harder the rock mass is, the higher the bearing capacity is and the higher the suitability of underground space development is.

(3) Hydrogeological conditions

Groundwater storage conditions and the groundwater depth have an important impact on the development of underground space. Underground engineering is vulnerable to the adverse effects of groundwater, which will damage the structure of underground engineering. The deeper the groundwater is, the more conducive to the 
development of underground space; the shallower the groundwater is, the less conducive to the development of underground engineering. The groundwater depth of Dalian city is $2-50 \mathrm{~m}$, and the groundwater is divided into four grades. In addition, considering storage conditions, groundwater is divided into four types, namely fissure water of bedrock, pore fissure water of clastic rock, fissure water of carbonate and pore water of loose deposits, which also represents the different levels of suitability for underground space development.

(4) Geological hazards

Geological hazards have adverse effects on the construction of underground space engineering. In this paper, Two indicators of susceptible zones of geological hazard and active faults are selected. The higher susceptible of geological hazard is, the less suitable for underground space development and construction. In addition, the $500 \mathrm{~m}$ buffer zone of active fault should be identified as the unsuitable zone for underground space development.

(5) Importance of ecological protection

All construction activities adhere to the principle of ecological priority. Underground space construction should try to avoid the extremely important area of ecological protection, and the extremely important area should be set as the unsuitable area for underground space development.

(6) Human activity

The strength of human activities can generally reflect the development demand of underground space. The light index is selected to reflect the economic development level of a certain area in this paper. The higher the light index level is, the higher the demand for underground space is. Therefore, the higher the light index level is, the higher the suitability of underground space development is.

Table 7 Grading and assignment of evaluation index

\begin{tabular}{|c|c|c|c|}
\hline Rule layer & Index layer & Grading standard & Score \\
\hline \multirow{4}{*}{ Topography } & \multirow{4}{*}{ Slope } & $<10^{\circ}$ & 10 \\
\hline & & $10-25^{\circ}$ & 6 \\
\hline & & $25-50^{\circ}$ & 3 \\
\hline & & $>50^{\circ}$ & 1 \\
\hline \multirow{4}{*}{$\begin{array}{l}\text { Engineering } \\
\text { geology }\end{array}$} & \multirow{4}{*}{$\begin{array}{l}\text { Rock mass } \\
\text { types }\end{array}$} & $\begin{array}{l}\text { Magmatic rock } \\
\text { formation }\end{array}$ & 10 \\
\hline & & $\begin{array}{c}\text { Metamorphic rock } \\
\text { formation }\end{array}$ & 6 \\
\hline & & Clastic rock formation & 3 \\
\hline & & Carbonate formation & 1 \\
\hline \multirow{8}{*}{$\begin{array}{l}\text { Hydrogeologi } \\
\text { cal condition }\end{array}$} & \multirow{4}{*}{$\begin{array}{c}\text { Groundwater } \\
\text { depth }\end{array}$} & $\geqslant 6 \mathrm{~m}$ & 10 \\
\hline & & $4-6 m$ & 6 \\
\hline & & $2-4 m$ & 3 \\
\hline & & $<2 \mathrm{~m}$ & 1 \\
\hline & \multirow{4}{*}{$\begin{array}{l}\text { Groundwater } \\
\text { types }\end{array}$} & $\begin{array}{l}\text { Fissure water of } \\
\text { bedrock }\end{array}$ & 10 \\
\hline & & $\begin{array}{c}\text { Pore fissure water of } \\
\text { clastic rock }\end{array}$ & 6 \\
\hline & & $\begin{array}{c}\text { Fissure water of } \\
\text { carbonate }\end{array}$ & 3 \\
\hline & & Pore water of loose & 1 \\
\hline
\end{tabular}

\begin{tabular}{|c|c|c|c|}
\hline Rule layer & Index layer & Grading standard & Score \\
\hline & & deposits & \\
\hline \multirow{8}{*}{$\begin{array}{l}\text { Geological } \\
\text { hazards }\end{array}$} & \multirow{4}{*}{$\begin{array}{l}\text { Susceptible } \\
\text { zones of } \\
\text { geological } \\
\text { hazard }\end{array}$} & No susceptible zone & 10 \\
\hline & & Low susceptible zone & 6 \\
\hline & & $\begin{array}{c}\text { Middle susceptible } \\
\text { zone }\end{array}$ & 3 \\
\hline & & High susceptible zone & 1 \\
\hline & \multirow{4}{*}{ Active fault } & $\begin{array}{c}\text { Outside of buffer area } \\
\text { of fault zone }\end{array}$ & 10 \\
\hline & & - & - \\
\hline & & - & - \\
\hline & & $\begin{array}{c}\text { Buffer area of fault } \\
\text { zone }\end{array}$ & 1 \\
\hline \multirow{4}{*}{$\begin{array}{l}\text { Ecological } \\
\text { factors }\end{array}$} & \multirow{4}{*}{$\begin{array}{l}\text { Importance of } \\
\text { ecological } \\
\text { protection }\end{array}$} & $\begin{array}{c}\text { Outside of extremely } \\
\text { important area }\end{array}$ & 10 \\
\hline & & - & $\longrightarrow$ \\
\hline & & - & - \\
\hline & & $\begin{array}{c}\text { Extremely } \\
\text { important area }\end{array}$ & 1 \\
\hline \multirow{4}{*}{$\begin{array}{l}\text { Human } \\
\text { activity }\end{array}$} & \multirow{4}{*}{ Light index } & level 1 & 10 \\
\hline & & level 2 & 6 \\
\hline & & level 3 & 3 \\
\hline & & level 4 & 1 \\
\hline
\end{tabular}

\section{Results}

By using the above comprehensive index method, the suitability of underground space development in Dalian city is comprehensively evaluated, and the evaluation results are divided into four grades. The results show that the areas of suitable area, secondary suitable area, less suitable area and unsuitable area are $3812.58 \mathrm{~km}^{2}$, $5430.91 \mathrm{~km}^{2}, 2711.38 \mathrm{~km}^{2}$ and $1659.06 \mathrm{~km}^{2}$, accounting for $28.00 \%, 39.89 \%, 19.92 \%$ and $12.19 \%$ respectively.

Table 8. Statistical table of suitability evaluation results of underground space in Dalian

\begin{tabular}{|c|c|c|c|}
\hline Order & Level & Area $\left(\mathrm{km}^{2}\right)$ & Proportion \\
\hline 1 & Suitable & 3812.58 & $28.00 \%$ \\
\hline 2 & $\begin{array}{c}\text { Secondary } \\
\text { suitable }\end{array}$ & 5430.91 & $39.89 \%$ \\
\hline 3 & Less suitable & 2711.38 & $19.92 \%$ \\
\hline 4 & unsuitable & 1659.06 & $12.19 \%$ \\
\hline
\end{tabular}

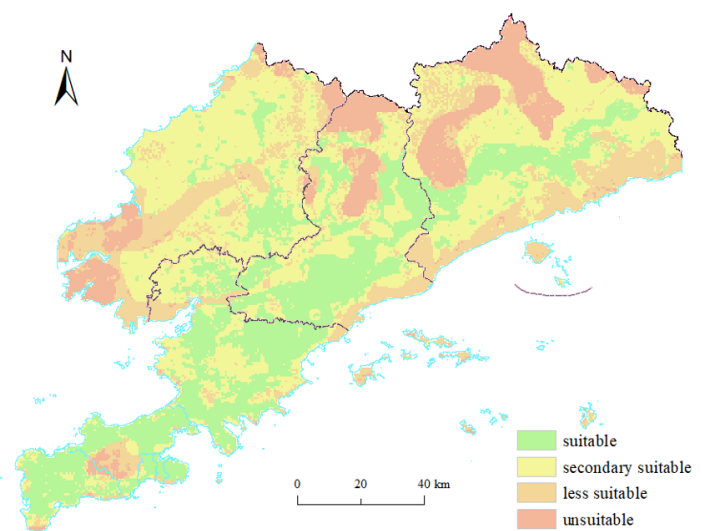

Fig.3. Suitability evaluation map of underground space development in Dalian City 


\section{Conclusions}

(1) On the basis of comprehensive analysis of geological environment conditions, eight indicators are selected from the aspects of topography, engineering geological conditions, hydrogeological conditions, geological hazards, ecological factors and human activities to construct the hierarchy model of geological environment suitability evaluation for underground space development in Dalian and the analytic hierarchy process and comprehensive index method are applied to the evaluation .

(2) The suitable area, secondary suitable area, less suitable area and unsuitable area are $3812.58 \mathrm{~km}^{2}$, $5430.91 \mathrm{~km}^{2}, 2711.38 \mathrm{~km}^{2}$ and $1659.06 \mathrm{~km}^{2}$, accounting for $28.00 \%, 39.89 \%, 19.92 \%$ and $12.19 \%$ respectively.

\section{Acknowledgments:}

This study was supported by China Geological Survey (No. DD20190506).

\section{References:}

1. Wout.B . (2016) Urban underground space: solving the problems of today's cities. Tunneling \& Underground Space Technology, Vol.55: 245-248.

2. Zhi L.C., Jia Y.C., Hong L., Zhang Z.F. (2018) Present status and development trends of underground space in Chinese cities: Evaluation and analysis. Tunnelling and Underground Space Technology incorporating Trenchless Technology Research, 71.

3. Zhang X.B., Wang C.S., Fan J., Wang H.J., Li H.L. (2020) Optimizing the analytic hierarchy process through a suitability evaluation of underground Space development in Tonghu District, Huizhou City. Energies, 13(3).

4. Tan F., Wang J., Jiao Y.Y. (2020) Current situation and trend of suitability evaluation of urban underground space at home and abroad. Earth Science:1-13.

5. Raymond R. L., Susan R. (1982) Nelson, Planning for underground space: a case study for Minneapolis.Minnesota: Minneapolis, Minn, Prepared by the underground Space Center, University of Minnesota.

6. De Rienzo F, Oreste P, Pelizza S.(2007)3D GIS supporting underground urbanisation in the city of Turin, 11th ACUUS international conferenceunderground space: expanding the frontiers, 397-402

7. Hao A.B., Wu Ai M, Ma Z.(2018)A Study of engineering construction suitability integrated evaluation of surface-underground space in Xiongan New Area. Acta Geoscientica Sinica, 39(05):513-522.

8. Zhang M.S., Wang H.Q., Dong Y., Li L., Sun P.P., Zhang G. (2020) Evaluation of urban underground space resources using a negative list method: Taking Xi' an City as an example in China. China Geology, Vol.3(1): 124-136.
9. Peng J., Liu K., Zheng F.T. (2010) Evaluation for the suitability of underground space exploitation and utilization Based on AHP. Chinese Journal of Underground Space and Engineering, 6(04):688-694.

10. He J., Zhou Y.X., Zheng G.S. (2020) Research on the geological suitability evaluation system of underground space resource utilization in Beijing. Chinese Journal of Underground Space and Engineering, 16(04):955-966. 